$\left[\begin{array}{l}\text { Jpn. J. Hosp. Pharm. } \\ \frac{\text { H }}{15} \text { (1) } \text { 設 }_{\text {文 }}^{55 \sim 59}{ }_{(1989)}^{\text {文 }}\end{array}\right]$

急性薬物中毒における血清中ブロムワレリル尿素の簡易比色定量*1

\author{
仲村裕子 $* 2$, 原 明宏 $* 2$, 近藤由利子 $* 2$, 森田美香 $* 3$, \\ 東祐太郎*3，滝沢徳正*3，河崎秀樹*3，由岐英剛*3 \\ 東邦大学医学部附属大森病院薬剤部*2 \\ 東邦大学薬学部臨床化学教室 $* 3$
}

\title{
A Simple Colorimetric Determination of Bromvalerylurea in Acute Toxipathic Patient's Serum
}

\author{
YUKO NAKAMURA*2, AKIHIRO HARA*2, YURIKO KONDOU*2, \\ MIKA MORITA*3, YUTAROU AZUMA*3, NORIMASA TAKIZAWA*3, \\ HIDEKI KAWASAKI*3, HIDETAKA YUKI*3 \\ Department of Pharmacy, Toho University Omori Hospital*2 \\ School of Pharmaceutical Science, Toho University*3
}

(Received June 6, 1988)

\begin{abstract}
A new method for the determination of bromvalerylurea (BVU) in the serum of acute toxipathic patients was developed. The serum was incubated with urease to hydrolyze urea which interferes with the determination of BVU. After deproteinization with trichloracetic acid, the sample solution was reacted with diacetylmonooxime, and the color developed was measured at $525 \mathrm{~nm}$. A straight calibration curve was obtained between 10 and $300 \mu \mathrm{g} \mathrm{BVU} / \mathrm{ml}$ serum. This method was simple and precise, and was applied to the acute toxipathic patient's serum.
\end{abstract}

Keywords_- serum bromvalerylurea; colorimetric determination; diacetylmonooxime; acute toxipathic patient

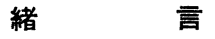

急性薬物中毒において，ブロムワレリル尿素 (BVU)

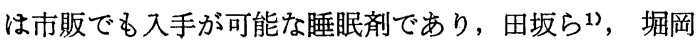
ら2) の報告によると，BVU は中毒原因物質として第 1 位となっている．臨床上BVUの急性中毒の場において， BVU の血清中濃度及び その推移を迅速に知ることは， その処置を行う上で非常に重要である，血清中の BVU

*1 本報の要旨は日本薬学会（第106年会, 千葉市）で 発表.

*2 東京都大田区大森西 6 丁 目 11-1；11-1, Omori Nishi 6-chome, Ota-ku, Tokyo, 143 Japan

*3 千葉県船 橋市三山 2 丁目 2-1；2-1, Miyama 2chome, Chiba-shi, 274 Japan
の定量法については, ブロム此色法 ${ }^{3)}, \mathrm{GC}$ 法4), HPLC 法5 7)等が報告されている.

著者らは，これまで操作が煩雑であった比色法に関し て, 尿素の定量法とされているジアセチルモノオキシム 法を応用することにより，BVU の簡易比色定量法確立 の検討を行った. さらに，本法をラット及び BVU 服用 患者血清について適応し, 短時間でその濃度を求めるこ とができた。

\section{実 験 方 法}

\section{1. 試薬及び試料}

BVUは日本新薬製，ジアセチルモノオキシム(DAM) 及びチオセミカルバゾン (TSC) は和光純薬製試薬特 級, 標準血清はネスコールX化血研を用いた.ウレアー 
ゼ（ナタ豆製）はシグマ社製 Type III のものを，活性 を測定した後使用した．DAM-TSC 試薬は, $1.2 \%$ DAM 水溶液及び $0.06 \% \mathrm{TSC}$ 水溶液を反応直前飞 等量混合 して用いた。 その他の試薬は，すべて市販特級規格品を 用いた。

\section{2. 装固及び器具}

装置 : 島津製作所社製ダブルビーム分光光度計 UV$200 \mathrm{~S}$

恒温槽: 大和社製インキュベータ BT222

遠心分離器 : 国産社製遠心分離器

ミキサー：サーモニクス社製 THERMO-MIXER

\section{TM105}

\section{3. 操作方法}

BVU の含まれる血清または血漿 $0.2 \mathrm{ml}$ に, ウレアー セ溶液 $0.1 \mathrm{ml}$ と $0.2 \mathrm{M}$ リン酸緩衝液 $(\mathrm{pH} 7.0) 0.2 \mathrm{ml}$ を加光, $37^{\circ} \mathrm{C}$ でインキュべートし, 尿素を分解する. $10 \%$ トリクロロ酢酸 (TCA) $0.3 \mathrm{ml}$ を加光遠沈して除蛋 白する.上澄液 $0.5 \mathrm{~m} 1$ を共柽つき褐色試験管にとり, DAM-TSC 試液 $0.5 \mathrm{ml}$ を加兄, 最終濃度が $5 \mathrm{~N}$ となる 上うに塩酸 $3 \mathrm{ml}$ を加光，水浴上で $100^{\circ} \mathrm{C} 20$ 分間加熱 し, 冷後 $525 \mathrm{~nm}$ で比色する.

\section{4. 検量線の作成}

10〜300 $\mu \mathrm{g} / \mathrm{m} 1$ 相当の BVU を添加した標準血清を調 製し，これを前述の方法に従って測定した．吸光度を BVU の濃度に対しプロットし検量線を得た。

\section{結果}

\section{1. 縮合反応時の溶媒の塩酸濃度}

縮合反応時飞拈いて，従来の DAM 直接法の通りリン 酸を用いると，BVU の感度は低く使用は困難であった． そこで溶媒を塩酸に変えたところ感度が上昇したため，
溶媒として塩酸を用いることとした。

その際の塩酸濃度と感度の関係を Fig.1 飞示した. 塩酸の濃度は $5 \mathrm{~N}$ のを゙最も感度が高かったので, 反応 時の塩酸をこの濃度とするため $6.67 \mathrm{~N}$ の塩酸を加える こととした.

\section{BVU 反応後の吸収スペクトルと安定性}

BVU 反応後の吸収スペクトルとその安定性を Fig.2 に示す. $525 \mathrm{~nm}$ で極大值が得られたため,測定は $525 \mathrm{~nm}$ で行うこととした．また，正常血清で同様僺作した場 合，この波長で吸収がわずかに見られたため，測定值か ら血清ブランク值を引くこととした。

反応後の吸光度は 6 時間後まで変化が見られず，測定 操作時間内で十分安定であった.

\section{3. 添加ウレアーゼ量の検討}

腎機能低下等の血清中尿素の増加した患者に 抽いて

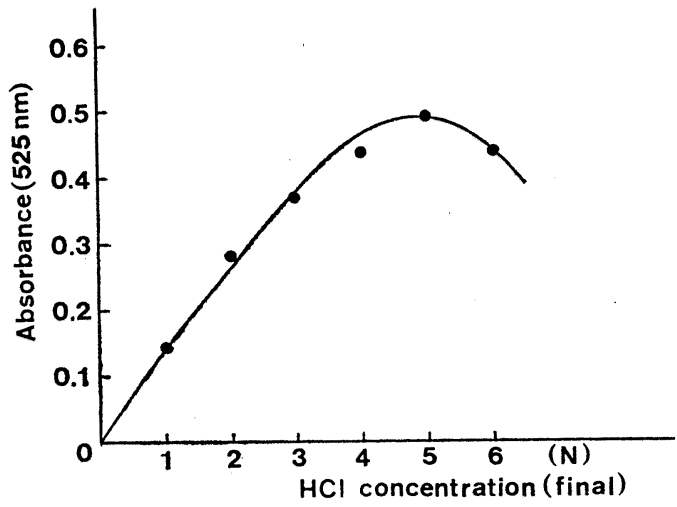

Fig.1. Effect of $\mathrm{HCl}$ Concentration on Color Development of BVU
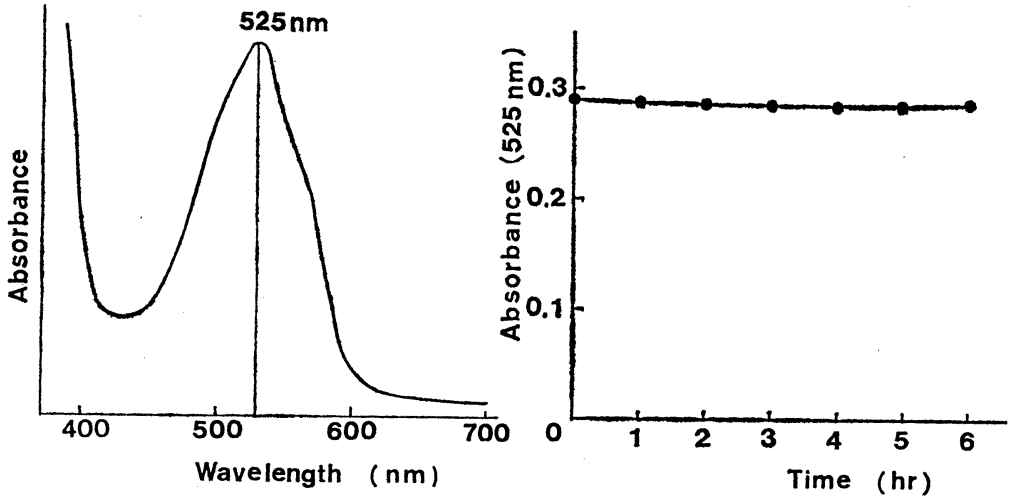

Fig. 2. Spectrum of Colored Reaction Product and Its Stability at Room Temperature 
も，尿素を完全に分解するだけのウレアーゼの量を決定 するために，正常血清にさらに尿素を $100 \mathrm{mg} / \mathrm{dl}$ の割合 で添加し，ウレアーゼの量を $10 ， 20 ， 30 ， 50 ， 70$ 国際単 位として実験を行った。 その結果を Fig. 3 と示す.

反応時間10分とした場合，用いるウレアーゼの量は， 10国際単位でも十分であったが，さらに安全を期して30 国際単位とした.

\section{4. 反応時間の検討}

DAM-TSC 試薬を加光た後の, 反応時間と呈色の強 さとの関係を検討するために, $100^{\circ} \mathrm{C} て ゙ 5$ 分間隔で 30 分 まで経時的に加熱し，吸光度の変化を観察した。Fig.4 に示すように，吸光度は20分でほぼ一定となったため， 加熱反応時間は20分とした.

な技，全体の操作を Fig. 5 に示した.

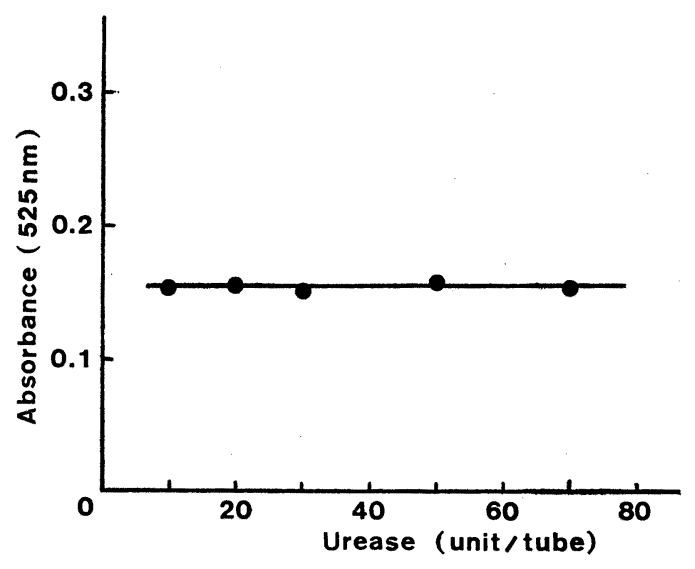

Fig.3. Determination of Urease Unit for Complete Hydrolysis of Serum Urea

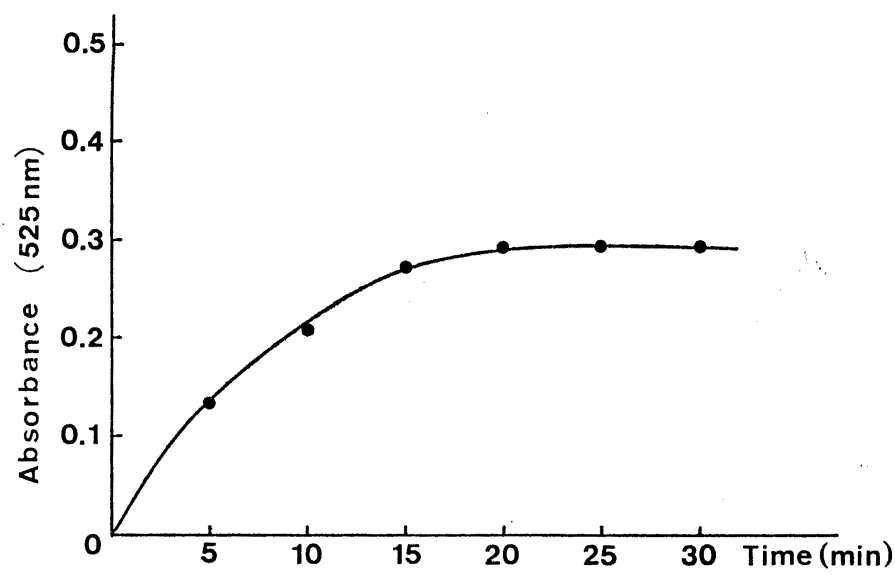

Fig.4. Effect of Reaction Time on Color Development of BVU

\section{5. 検量線の検討}

BVU10 300 $\mu \mathrm{g} / \mathrm{ml}$ 相当を涯加した標準血清を作成後， 本法の条件下で測定した結果, $\mathrm{y}=2.13 \times 10^{-3} \mathrm{x}+6.29 \times$ $10^{-4}(n=11)$, 相関俰数 0.999 の良好な直線性が得られ た (Fig.6).

また，それより低濃度の $10 \sim 100 \mu \mathrm{g} / \mathrm{ml}$ の BVU 添加 血清についても検量線を作成したが，同様に $\mathrm{y}=1.99 \times$ $10^{-3} \mathrm{x}+2.69 \times 10^{-4}(\mathrm{n}=11)$ ，相関係数 0.999 の良好な直 線性が得られた。

\section{6. 再現性の検討}

BVU 10，50，100 $\mathrm{g} / \mathrm{ml}$ を含む血清について本法で 行った再現性及び回収率の結果を Table 1 飞示した. いずれる良好な結果が得られたが，同時再現性，日差再 現性ともに $10 \mu \mathrm{g} / \mathrm{ml}$ 飞执ける変動係数が $50,100 \mu \mathrm{g} / \mathrm{ml}$
1) Serum or standard solution $\cdots \cdots \cdots \cdots \cdots \cdots, 0.2 \mathrm{ml}$ Buffer solution $\mathrm{pH} 7.0 \ldots \ldots \ldots \ldots \ldots \ldots \ldots .2 \mathrm{ml}$ Urease solution …...................... $0.1 \mathrm{ml}$ Incubation at $37^{\circ} \mathrm{C}$ for $10 \mathrm{~min}$.

2) $10 \%$ TCA solution …................... $0.3 \mathrm{ml}$ $3000 \mathrm{rpm}$ for $10 \mathrm{~min}$.

3) Supernatant ……....................... $0.5 \mathrm{ml}$

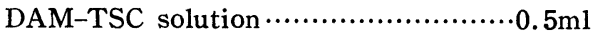

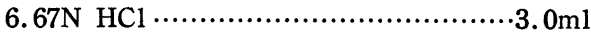

Heating at $100^{\circ} \mathrm{C}$ for $20 \mathrm{~min}$.

4) Measurement at $525 \mathrm{~nm}$

Fig. 5. Procedure for the Determination of BVU in Serum 

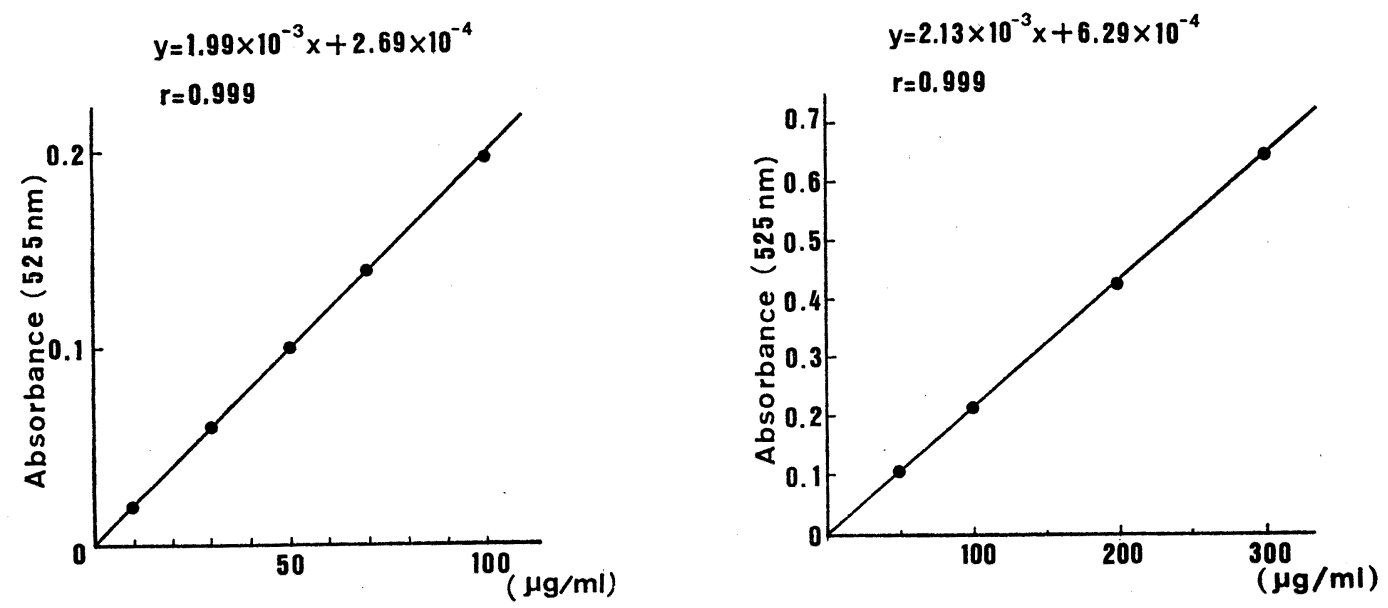

Fig. 6. Calibration Curves of BVU

Table 1. Precision and Recovery in Determination of BVU in Serum

\begin{tabular}{|c|c|c|c|c|}
\hline \multirow{2}{*}{$\begin{array}{c}\text { BVU } \\
(\mu \mathrm{g} / \mathrm{ml})\end{array}$} & \multicolumn{2}{|c|}{ Within-run $(n=8)$} & \multicolumn{2}{|c|}{ Between-run $(n=8)$} \\
\hline & $\underset{(\mu \mathrm{g} / \mathrm{ml})}{\operatorname{Mean} \pm S . D .}$ & C.V. & $\underset{(\mu \mathrm{g} / \mathrm{ml})}{\operatorname{Mean} \pm S . D}$ & C. V. \\
\hline 10.0 & $9.8 \pm 0.7$ & 7.46 & $9.3 \pm 0.8$ & 8.13 \\
\hline 50.0 & $48.2 \pm 0.9$ & 1.92 & $46.7 \pm 1.7$ & 3.59 \\
\hline 100.0 & $95.4 \pm 1.8$ & 1.90 & $89.5 \pm 2.9$ & 3.21 \\
\hline
\end{tabular}

\begin{tabular}{c|c|c}
\hline & $\begin{array}{c}\text { Concentration } \\
(\mu \mathrm{g} / \mathrm{ml})\end{array}$ & $\begin{array}{c}\text { Recovery } \\
(\%)\end{array}$ \\
\hline BVU & 10.0 & 99.1 \\
& 50.0 & 96.0 \\
& 100.0 & 95.7 \\
\hline
\end{tabular}

に比較して大きくなったため， $10 \mu \mathrm{g} / \mathrm{ml}$ の濃度が定量限 界と思われる。

\section{7. 交差反応の桧討}

本法は，BVU の尿素構造による反応を用いた定量法 であるため，尿素構造を有する薬物を併用していた場 合，その交差反応が問題となる. そのため尿素構造を有 する薬物また薬物中毒で上位にランクされるものについ て，BVU との交差性の検討を行った．BVU $100 \mu \mathrm{g} / \mathrm{ml}$ の標準液に同濃度の他剤を添加し 測定を行った. 結果 は, BVU のみのものを $100 \%$ として表した.

Table 2 に示すよらに, アセチル尿素は反応機構上当 然高い值を示したが，この物質は医薬品として用いられ
Table 2. Cross Reaction of Various Substances $(100 \mu \mathrm{g} / \mathrm{ml})$ Mixed with BVU $(100 \mu \mathrm{g} / \mathrm{ml})$

\begin{tabular}{lc}
\hline Additives & BVU found \\
\hline BVU only & $100.0(\%)$ \\
Acetylurea & 353.2 \\
Urea & 99.0 \\
\hline Acetylpheneturide & 158.0 \\
Phenobarbital & 99.5 \\
Nitrazepam & 94.7 \\
Phenytoin & 90.0 \\
Chlorpromazine & 95.8 \\
Carbamazepine & 96.3 \\
Estazolam & 105.0 \\
Diazepam & 104.5 \\
Medazepam & 104.5 \\
Levomepromazine & 100.0 \\
Bromazepam & 95.0 \\
\hline
\end{tabular}

ることはない，点線以下が医薬品として使用されるもの であるが，部分的にアセチル尿素の構造を有しているア セチルフェネトライドのみ高い値を示した．尿素及びフ ェノバルビタール以下のものについては, この測定法に 影響を与えなかった。

また，ビリルビン血清に関しても検討したが，20mg/ dl までは影響が見られなかった。

8. ラット血清中 BVU の測定

体重 280 310g のラットに人間の極量, 致死量, 致 
Table 3. BVU Concentration in Rat Serum at One Hour after Oral Administration

\begin{tabular}{c|c|c|c}
\hline $\begin{array}{c}\text { Rats } \\
\text { No. }\end{array}$ & $\begin{array}{c}\text { Body Weight } \\
(\mathrm{g})\end{array}$ & $\begin{array}{c}\text { Dose } \\
(\mathrm{mg} / \mathrm{kg})\end{array}$ & $\begin{array}{c}\text { BVU in Serum } \\
(\mu \mathrm{g} / \mathrm{ml})\end{array}$ \\
\hline 1 & 295 & $40^{*}$ & N.D. \\
2 & 280 & $200^{* *}$ & 26.2 \\
3 & 310 & 200 & 24.1 \\
4 & 295 & 600 & 42.5 \\
5 & 290 & 600 & 55.3 \\
\hline
\end{tabular}

* : maximum dose for man

** : lethal dose for man

N.D. : not detected

死量の 3 倍にあたる $40,200,600 \mathrm{mg} / \mathrm{kg}$ の割合で BVU を経口投与し，投与後 1 時間に採血し，その血清につい て測定を行った. その結果, $200,600 \mathrm{mg} / \mathrm{kg}$ の割合で 投与したものについては, Table 3 に示す測定值が得ら れた. 極量に相当する $40 \mathrm{mg} / \mathrm{kg}$ 投与したものからは, BVU は検出されなかった.

\section{9. 臨床例}

某 BVU 中毒患者の血中濃度測定について, 経時的に 採血し測定を行った. 患者は, 12月22日19時服薬後約 7 時間に当院 ICU に意識障害, 呼吸抑制の状態で入室し た. 薬ビンがそばにあったこと，レントゲン所見等から BVU 中毒であると診断された。 直ちに胃・腸洗浄, 強 制利尿, 血液透析が施行された。

12月22日20時 BVU 服用後約 8 時間の血液透析前の血 中濃度は $113 \mu \mathrm{g} / \mathrm{ml}$ であり, 乎名反応, 痛覚反応ともに なかった. 翌朝12月23日の血中濃度は $56 \mu \mathrm{g} / \mathrm{ml}$ であり， 徐々に呼名反応, 痛覚反応に応じるようになり, 意識も 回復した. 服薬 3 日後, 12 月 25 日 8 時の BVU 血中濃度 は，検出限界以下であった。

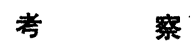

尿素の臨床検査法の 1 つとして行われているジアセチ ルモノオキシム法は, 尿素を強酸の存在下 DAM と TSC とを反応させて呈色させる方法である．この反応では， DAM が TSC と縮合してチオセミカルバゾンを形成 し，さらにこれが尿素と数段階の反応後，2-amino-5, 6 -dimethyl-2,3-dihydrotriazine-3-one を形成する。 こ の物質は酸性溶液中でプロトネーションを起こし, 赤く 呈色することが明らかにされている8).

BVU は尿素構造を有するため，DAM による比色法 の適応が可能であろうと考劣，この方法の応用を検討し
た、しかし，血清中の尿素は当然妨害となるため，この 尿素をウレアーゼで分解除去を試みた. この場合ウレア 一ゼは特異性が高く，BVU に作用することはないと考 えられる.

ヒトでの BVU 中毒の際の血中濃度は真口らの報告9 によると $\mathrm{Br}$ 量として $20 \sim 50 \mu \mathrm{g} / \mathrm{ml}$ (BVU として 55.8 〜 $140 \mu \mathrm{g} / \mathrm{ml}$ ) であり, Essen らによると BVU 中毒患者 の血清中濃度が $90 \mu \mathrm{g} / \mathrm{ml}$ であったと報告されている10). また田坂らは予後判定の基準を $100 \mu \mathrm{g} / \mathrm{ml}$ としている1). 本法の定量限界は HPLC 法に比してやや低いが；10 $\sim 300 \mu \mathrm{g} / \mathrm{ml}$ の範囲の BVU の血中濃度測定が可能であ るので, 上記の文献 ${ }^{9,10)} や 今$ 回の臨床例から考えて, 本 法はその簡便性により，BVU 急性中毒患者に対し実際 的な適用が可能であると考えられる.

$$
\text { ま と め }
$$

BVU 中毒患者の 血清中濃度測定方法を検討した. BVU は尿素構造を有するため, 血清中の尿素をあらか じめウレアーゼで分解除去した後, DAM にて BVUを 呈色させることによる簡易比色定量法を開発することが できたこの方法は臨床的な応用が可能と考えられる.

謝辞 ラットへの BVUの投与並びにその採血にご協 力下さいました, 東邦大学薬学部臨床化学教室の長谷川 幸雄助手に感謝します.

\section{引用 文 献}

1）田坂定孝, 清水喜八郎, 国井乙彦, 日本医 事 新 報. No. 1879, 3 (1960).

2）堀岡正義, 藤井俊志; 外科診療, 24, 796 (1982).

3）日本薬学会編, “薬毒物試験法注解第 3 版”, 南 山堂, 1985 , p. 89.

4) 小鳯 亨, 日法医誌, 25, 59 (1971)

5) D.R.A.Uges and P.Bouma, Arch. Toxicol., 42, 85 (1979).

6) 岡本光美, 山田不二造, 石黒源之, 梅村厚志, 薬 誌, 100, 675 (1980).

7）西原カズョ, 幸田幸直, 小滝 一, 斎藤侑也, 森 田博, 堤 晴彦, 豊岡秀訓, 三井香坚, 分析化学, 35, 272 (1986).

8) H. Yuki, T.Ohmura, H.Kawasaki, T.Yajima and K. Saito, Chem. Pharm. Bull., 29, 1096 (1981).

9) 真口孝順, 北海道医学雑誌，36，559 (1961).

10) E.J.Essen, J.C.Csanky-Treels, M. C. Th. F. M.Krom and M.M.Tjoeng, Arch. Toxicol., 44, 299 (1980). 